\title{
Marker-assisted selection of maintainer lines within an onion tropical population
} \author{
Marciene Amorim Rodrigues ${ }^{1}$ \\ ${ }^{1}$ Embrapa Semi-Árido, C.P. 23 - 56302-970 - Petrolina, PE - Brasil. \\ ${ }^{2}$ Embrapa Clima Temperado, C.P. 403 - 96001-970 - Pelotas, RS - Brasil. \\ ${ }^{3}$ Embrapa Hortaliças, C.P. 218 - 70359-970 - Brasília, DF - Brasil. \\ *Corresponding author < casantos@cpatsa.embrapa.br>
}

Carlos Antonio Fernandes Santos ${ }^{1 *}$; Daniela Lopes Leite²; Valter Rodrigues Oliveira ${ }^{3}$;

\begin{abstract}
The traditional onion (Allium cepa) hybrid production requires the development of maintainer and male sterile lines and also a pollinator line with good specific combination ability. We report the identification of maintainer and male-sterile onion lines within the Brazilian 'Baia Periforme' derived population, 'Alfa São Francisco', associating random field pairing of male-fertile plants with selected male-sterile plants and PCR-based marker system monitoring S, T and N-cytoplasms. Male-sterile plants produced flowers with light green anthers which were easily detected in the field. A frequency of $2.0 \%$ of male-sterile plants was estimated in the 'Alfa São Francisco' sampled population. Male-sterile plants produced the 5' cob-marker 180-bp and the orfA501-marker 473-bp fragments, suggesting the T-cytoplasm type, while the maintainer line produced only the $5^{\prime}$ cob-marker $180-\mathrm{bp}$. These identified lines will be important to develop tropical onion hybrids welladapted to Brazilian low latitudes and to future comparative studies with other onion cytoplasmic genic male sterility systems.

Key words: Allium cepa, CMS, 'Alfa São Francisco', tropical hybrid
\end{abstract}

\section{Seleção assistida por marcadores de linha mantenedora dentro de uma população de cebola tropical}

\begin{abstract}
RESUMO: A produção tradicional de híbrido de cebola (Allium cepa) requer o desenvolvimento de linhas mantenedoras e linhas macho estéreis, bem como uma linha polinizadora de boa capacidade específica de combinação. Reporta-se a identificação de linhas de cebola mantenedora e macho-estéreis numa população 'Alfa São Francisco' derivada da brasileira 'Baia Periforme', associando pareamento ao acaso no campo de plantas férteis com plantas macho-estéreis e sistema de PCR para monitoramento dos citoplasmas S, T e N. Plantas macho-estéreis produziram flores com anteras verde-claras, que foram facilmente identificadas no campo. A freqüência de 2,0\% de plantas macho-estéreis foi estimada dentro de uma amostra da população 'Alfa São Francisco'. Plantas macho-estéreis produziram o marcador 5' cob de 180-pb e o marcador orfA501 de 473-pb, sugerindo que o citoplasma é do tipo T, enquanto a linha mantenedora da macho-esterilidade produziu apenas o marcador 5 ' cob de 180-pb. Essas linhas identificadas serão importantes para o desenvolvimento de híbridos de cebola tropical, bem adaptados às áreas de baixa latitude do Brasil e para estudos comparativos no futuro com outros sistemas da macho-esterilidade citoplasmática gênica de cebola.
\end{abstract}

Palavras-chave: Allium cepa, CMS, 'Alfa São Francisco', híbrido tropical

\section{Introduction}

The production of hybrid seeds of onion (Allium cepa L.) became economically feasible with the discovery of cytoplasmic-genic male-sterility (Jones and Clarke, 1943). In addition to normal male-fertile $\mathrm{N}$-cytoplasm, three male-sterile cytoplasms have been used in onion hybrid seed production: S, C and T (Szklarczyk et al., 2002). The identification of these cytoplasms was greatly facilitated with the development of specific DNA markers associated to specific types of onion cytoplasms by Polymerase Chain Reaction PCR (Havey, 1995; Sato, 1998; Engelke et al., 2003). The combination of the 5' cob (Sato, 1998) and orfA501- markers allowed distinguishing between all three cytoplasm types in individual plants a few weeks after sowing (Engelke et al., 2003).

There has been a recent shift recently from openpollinated (OP) to hybrid onion in many countries (Serra and Currah, 2002). The semi-arid Brazilian regions of the States of Pernambuco and Bahia account for $18 \%$ of the national onion production, and the most important grown OPs. Two main reasons account for the large use of OPs in the region: (i) the price of hybrid onion seeds is four to five-fold that of the OP seeds, and (ii) many available hybrids are susceptible to anthracnose caused by the fungus Colletotrichum gloeosporioides (Melo and Boiteux, 2001). 
Previous attempts to identify maintainer (line ' $\mathrm{B}$ ') and male-sterile lines (line ' $\mathrm{A}$ ') have led to the molecular identification of only fertile cytoplasm in the 'Alfa Tropical' population (Leite, 1999) and to the identification, by morphological test-cross screening, of both ' $\mathrm{A}$ ' and ' $\mathrm{B}$ ' lines within the 'Baia Periforme Precoce Piracicaba' population (Costa, 1967). To date these studies have not led to the development of a commercial hybrid based on long-time adapted Brazilian onion populations.

Here we report the identification of lines ' $A$ ' and ' $B$ ' within the 'Baia Periforme' derived onion population, 'Alfa São Francisco', based on a PCR marker system monitoring cytoplasm type and by random field pairing of fertile plants with selected sterile plants. These identified lines will be important to develop tropical onion hybrids well-adapted to Brazilian low latitudes.

\section{Material and Methods}

Plant material and onion cytoplasmic genic male sterility (CMS) maintainer screening

Screening for male-sterile and maintainer plants was performed within the 'Alfa São Francisco' onion population. This population was derived after five cycles of phenotypic recurrent selection in the 'Alfa Tropical' onion population. 'Alfa Tropical' was developed after eleven cycles of phenotypic recurrent selection in a base population constituted from an open polycross among eleven varieties of 'Baia Periforme' onion type (Araújo and Rodrigues, 1998).

Sterile plants were identified in the field by visual identification of open flowers without pollen and they were randomly paired with surrounding fertile plants. Paired plants or individual sterile plants were caged with flies in order to produce seeds. Seeds of a pair were harvested separately to produce the next generation. After vernalization in a cold chamber, bulbs were grown in the field for a new screening. To be considered a potential maintainer, a pair has to have sterile progenies from the previous sterile plant and fertile progenies from the previous fertile plant. Test-crossing were performed with selected pairs, one from 2005 to 2006 and another from 2007 to 2008. Only a potential maintainer, $16 \mathrm{~F} 1 \mathrm{~F} 1$, was common in these two test-crosses.

\section{DNA extraction and amplification}

Total DNA was isolated from onion leaf tissue following the protocol by Doyle and Doyle (1990), with minor modifications. After grinding in liquid nitrogen, about $0.2 \mathrm{~g}$ of the powdered tissue was suspended in 900 $\mu$ L CTAB $2 x$ extraction buffer $[100 \mathrm{mM}$ Tris $\mathrm{pH}$ 8.0, 1.4 $\mathrm{M} \mathrm{NaCl}, 2 \%(\mathrm{w} / \mathrm{v})$ CTAB, $2.0 \%$ beta-mercaptoethanol, $20 \mathrm{mM}$ EDTA] and incubated at $60^{\circ} \mathrm{C}$ for $30 \mathrm{~min}$ with occasional mixing by gentle tube inversion. Nine-hundred $\mu \mathrm{L}$ chloroform:isoamyl alcohol $(24: 1 \mathrm{v} / \mathrm{v})$ was added, and the solution was mixed by inversion to form an emulsion that was centrifuged at $8,000 \mathrm{x}$ g for $10 \mathrm{~min}$ at room temperature. The aqueous phase was removed to a new Eppendorf tube, and 2/3 volume of ice-cooled isopropanol was added and mixed by gentle inversion. After $20 \mathrm{~min}$ in an ice tray, the solutions were centrifuged at $16,500 \mathrm{xg}$ for $10 \mathrm{~min}$. The pellet was allowed to air-dry for up to $2 \mathrm{~h}$ and resuspended in $20 \mu \mathrm{L}$ of TE buffer. After RNAse treatment to remove co-isolated RNAs, the total DNA quantity and integrity was estimated on $0.8 \%$ agarose gels.

PCR was performed as described by Engelke at al. (2003). The reaction mixture of the 5' cob-marker with three primers was incubated in a thermocycler for $2 \mathrm{~min}$ at $94^{\circ} \mathrm{C}$, followed by 40 cycles: $30 \mathrm{~s}$ at $94^{\circ} \mathrm{C}, 1 \mathrm{~min}$ for annealing at $53^{\circ} \mathrm{C}, 2 \mathrm{~min}$ at $72^{\circ} \mathrm{C}$ and a final extension for $5 \mathrm{~min}$ at $72^{\circ} \mathrm{C}$. The reaction mixture of the orfA501marker with two primers was incubated in a thermocycler for 2 min at $94^{\circ} \mathrm{C}$, followed by 40 cycles: $30 \mathrm{~s}$ at $94^{\circ} \mathrm{C}, 70 \mathrm{~s}$ for annealing at $54^{\circ} \mathrm{C}, 2 \mathrm{~min}$ at $72^{\circ} \mathrm{C}$ and a final extension for $5 \mathrm{~min}$ at $72^{\circ} \mathrm{C}$. PCR-products were separated by flatbed electrophoresis using $1.5 \%$ agarose gels in $1 \mathrm{x}$ TAE buffer.

Onion cytoplasms were identified according to Engelke et al. (2003): i) in the N-cytoplasm only the 180bp fragment of the $5^{\prime}$ cob-marker is amplified; ii) in the T-cytoplasm the fragments 180 -bp of the 5' cob-marker and 473-bp of orfA501 are amplified; and iii) in the Scytoplasm fragments of 180-bp and 414-bp of the 5' cobmarker and fragment of 473-bp of orfA501 are amplified.

\section{Results and Discussion}

\section{Field morphological identification of male-sterile plants}

Male-sterile plants in the 'Alfa São Francisco' onion population produced flowers easily detected with light green anthers and when the anthers were squeezed between thumb and finger they did not leave any trace of pollen. Caging sterile plants with flies to force self-pollination did not produce seeds, indicating that flowers with light green anthers were reliable sterile-plants.

A frequency of $2.0 \%$ of male-sterile plants was estimated in around 1,500 plants of the 'Alfa São Francisco' with an average of 2.0 umbels per plant, which reduced the number to two randomly surrounded fertile-plants. Estimated frequencies of male-sterile plants have ranged from $12.9 \%$ to $1.0 \%$ in the Brigham Yellow Globe and Texas Grano 1015Y onion populations, respectively (Havey, 1995). Leite (1999) failed to find male sterile plants within the 'Alfa Tropical' by molecular screening which may have been due to some sample size problem because in the 'Alfa São Francisco', which was derived from 'Alfa Tropical', we have field-screened at least 1,500 plants.

\section{Field morphological identification of onion CMS maintainer line}

Random field pairing of fertile plants with selected sterile plants produced 90 pairs and only the $16 \mathrm{E} 1$ $(\mathrm{E}=$ sterile $) \times 16 \mathrm{~F}(\mathrm{~F}=$ fertile $)$ pair presented the onion CMS maintainer conditions in the first test-crossing: all 
sterile progenies from the genitor male sterile plant and all fertile progenies from the male fertile plant. Only the potential maintainer 16F1F1 (meaning pair 16, first and second F1 of the first and second test-crossing, respectively) produced seeds in the second test-crossing. A second test-crossing was performed with the potential maintainer 16F1F1 paired with other four male-sterile plants from the previous test-crossing. All pairs produced the desired maintainer conditions.

\section{Marker-assisted identification of onion CMS main- tainer line}

In the second test-crossing of the first two pairs were identified with normal cytoplasm and sterile cytoplasm $(16 \mathrm{E} 1 \mathrm{E} 1 \times 16 \mathrm{~F} 1 \mathrm{~F} 1$ and $16 \mathrm{E} 1-\mathrm{E} 2 \times 16 \mathrm{~F} 1-\mathrm{F} 2)$, because only the sterile progenies produced the 180-bp fragment of the $5^{\prime}$ cob-marker (Figure1). Further work with the pair 16E1-E2 $\times 16 \mathrm{~F} 1-\mathrm{F} 2$ resulted in abnormal flowers and no seed production was obtained. Only the potential maintainer $16 \mathrm{~F} 1 \mathrm{~F} 1$ produced seed for further molecular investigations.

Male-sterile plants identified in a seed increasing of 'Alfa São Francisco' and male-sterile from the first test- crossing were paired with line 16F1F1 and they produced only the 180-bp fragment of the 5' cob-marker in the $16 \mathrm{~F} 1 \mathrm{~F} 1$ plants $(6 \mathrm{~F}, 7 \mathrm{~F}, 5 \mathrm{~F}, 9 \mathrm{~F}, 16 \mathrm{~F}, 14 \mathrm{~F}$ and $15 \mathrm{~F})$ and the 180-bp fragment of the 5' cob-marker and 473-bp fragment of the orfA501-marker, respectively, suggesting that the $\mathrm{N}$ and $\mathrm{T}$-cytoplasms were present in the $16 \mathrm{~F} 1 \mathrm{~F} 1$ and male-sterile plants, respectively, in this new test-crossing. Of the ten plants grown as potential maintainer lines, three reproduced the same fragment of male sterile lines (3F, 4F and 8F) (Figure 2).

A second test-cross with two bulks of plants produced the $\mathrm{T}$ and $\mathrm{N}$-cytoplasms in all male-sterile and in 161F1F1 plants, respectively (Figure 3), suggesting that a stable CMS system was found within the Brazilian tropical 'Alfa São Francisco' onion population. The presence of N and T-cytoplasms in the 'Alfa São Francisco' onion population could be a result of the base population from which it was developed, that involved a polycross of onion populations, including 'Baia Periforme Super Precoce', 'Chata IPA 5', 'Roxa IPA3', 'Pêra IPA 2', 'Baia do Cedo', 'Pira Ouro' and 'Pira Tropical'.

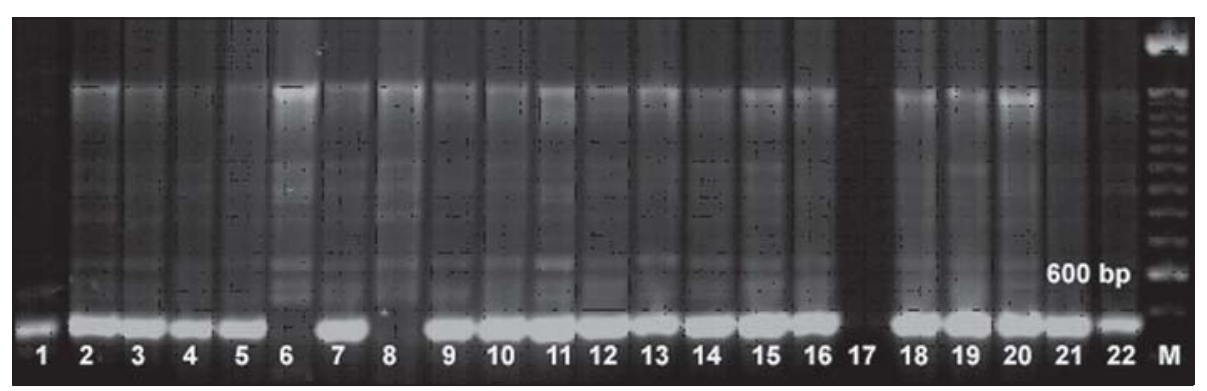

Figure 1 - Amplicons of the orfA501-marker (Engelke et al., 2003) in ten pairs of random field pairing of fertile plants (F) with selected sterile plants (E) of the "Alfa São Francisco" onion population: (1) 6E2-E1 × (2) 6F2-F1, (3) 6E2-E2 × (4) 6F2F2, (5) $16 \mathrm{E} 1 \mathrm{E} 1 \times(6) 16 \mathrm{~F} 1 \mathrm{~F} 1,(7) 16 \mathrm{E} 1-\mathrm{E} 2 \times(8) 16 \mathrm{~F} 1 \mathrm{~F} 2$, (9) P27-E1, (10) $59 \mathrm{E} 1 \times(11) 59 \mathrm{~F} 1,(12) 31 \mathrm{E} 1 \times(13) 31 \mathrm{~F} 1,(14)$ $90 \mathrm{E} 2 \times(15) 90 \mathrm{~F} 2,(16) 90 \mathrm{E} 3 \times(17) 90 \mathrm{~F} 3,(18) 178-1 \mathrm{E} \times(19) 178-1 \mathrm{~F},(20) \mathrm{P} 184-\mathrm{E} 1$, (21) P188-E1, (22) Crioula 5. M = DNA size marker $100 \mathrm{~kb}$ plus.

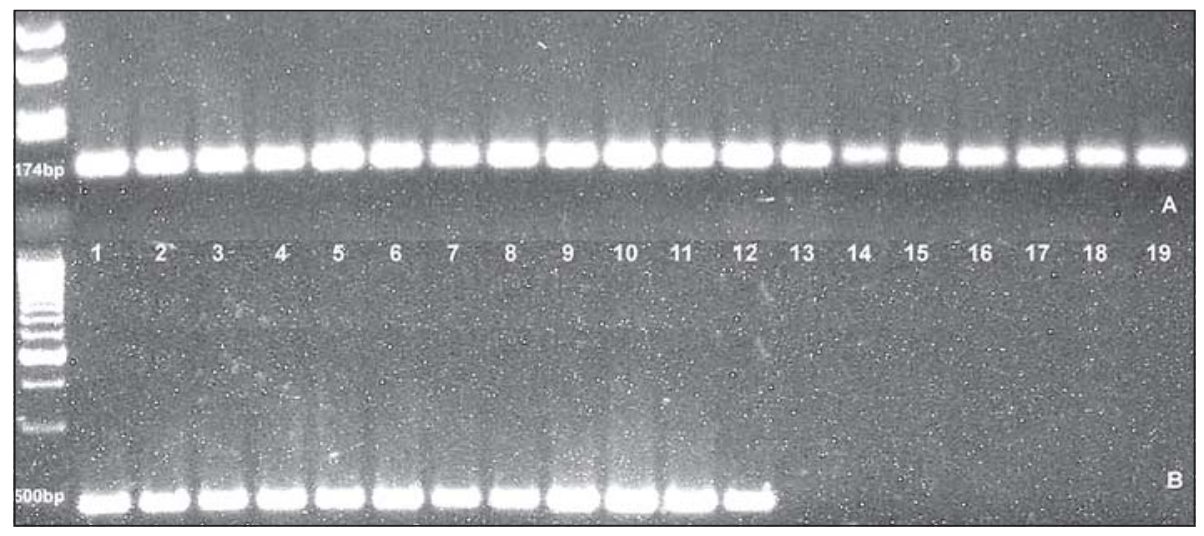

Figure 2 - Amplicons of the 5' cob-marker (Sato, 1998) (panel A) and the orfA501-marker (Engelke et al., 2003) (panel B) in eight pairs of random field pairing of fertile plants $(\mathrm{F})$ with selected sterile plants (E) of the "Alfa São Francisco" onion population: (1) $3 \mathrm{E} \times(10) 3 \mathrm{~F},(2) 4 \mathrm{E} \times(11) 4 \mathrm{~F},(3) 8 \mathrm{E} \times(12) 8 \mathrm{~F},(4) 6 \mathrm{E} \times(13) 6 \mathrm{~F},(5) 7 \mathrm{E} \times(14) 7 \mathrm{~F},(6) 5 \mathrm{E} \times(15) 5 \mathrm{~F}$, (7) $9 \mathrm{E} \times(16) 9 \mathrm{~F},(8) 17 \mathrm{E},(9) 18 \mathrm{E},(17) 16 \mathrm{~F},(18) 14 \mathrm{~F}$ and (19) 15F. Panel A: M = DNA size marker 50 bp Amresco. Panel $\mathrm{B}: \mathrm{M}=\mathrm{DNA}$ size marker $500 \mathrm{bp}$ Invitrogen. 


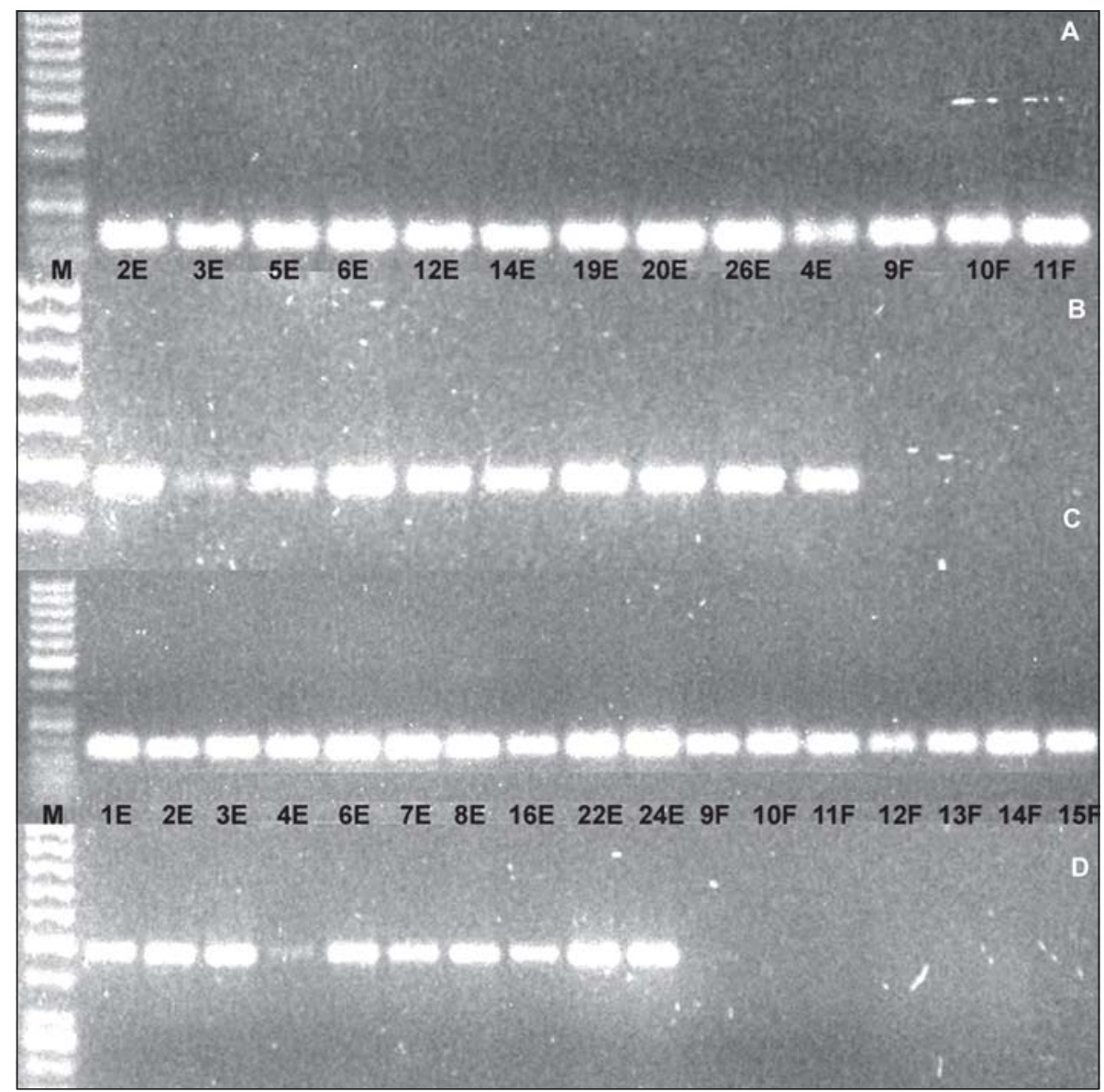

Figure 3 - Amplicons of the 5' cob-marker (Sato, 1998) (panel A and C) and the orfA501-marker (Engelke et al., 2003) (panel B and D) in two bulks of lines 'A' and 'B': sterile progenies of P49 E1 SP $\times$ fertile 16F1F1 (panels A and B) and sterile progenies of Alfa VII SP x fertile 16F1F1 (panels $\mathrm{C}$ and D) $\mathrm{M}=$ DNA size marker 50 bp Fermentas.

The first reported male-sterile plant of S-cytoplasm produced brown and shriveled flowers with unviable pollen (Pathak, 1997). Pathak (1997) also reported a possible new source of male sterility in onion, which presented flowers with light green anthers. Despite the presence of similar male-sterile anther color, no parallel can be established in this study between the Pathak system and the system that we are reporting in 'Alfa São Francisco'.

Banga and Petiet (1958), in Holland, and Costa (1967), in Brazil, reported successful identification of maintainer lines by random pairing with male-sterile plants of the same onion landrace population after four years of field work. Here we report the identification of a maintainer and male-sterile onion lines within the 'Alfa São Francisco' population, after two successive test-crossing performed in two years under Brazilian Semi-Arid conditions. Onion production from seed to seed is possible in the region in one year because bulbs can be produced in four months after sowing, bulbs can be vernalized for one hundred days in a cold chamber, and growing vernalized bulbs can produce seed in three to four months.

Only two PCR reactions were necessary to confidently identify the type of onion cytoplasm with the Engelke et al. (2003) and Sato (1998) primers: one with
' $\mathrm{C}$ ', 'S' and ' $\mathrm{N}$ ' primers of the 5' cob-marker and the other with the two primers of the orfA501-marker. No faint fragment was observed with the 5' cob-marker primers, as reported by Szklarczyk et al. (2002). The 40 PCR cycles were enough to amplify the small quantity of coisolated mitochondrial DNA with total genomic DNA, without the laborious and expensive protocols to extract vegetable cytoplasm as originally demonstrated by Engelke et al. (2003).

As reviewed by Pathak (1997), there are three recessive genes in the T-CMS system: plants with the 'aa' gene and T-cytoplasm are male sterile, and the complementary genes ' $b$ ' and ' $c$ ' in the form of 'bbcc' in presence of T-cytoplasm are also male sterile. According to Pathak (1997), the complex inheritance of T-CMS hinders its use and in many situations in Europe the fertility restoring lines of S-CMS were used as sterility maintainers of T-cytoplasm sterile plants. We are predicting that this will not be a problem because we have obtained an excellent seed production in both sterile and fertile plants in the second test-cross in the "Alfa São Francisco'.

The $\mathrm{N}$ and T-cytoplasms have been identified, with the PCR-based marker system monitoring cytoplasm 
developed by Sato (1998) and Engelke et al. (2003), in many Brazilian onion populations such as 'Pera Norte', 'Bola Precoce', 'Baia Periforme', 'BRS Cascata', 'Conquista', 'Vale Ouro IPA 11', 'Jubileu', 'Baia do Cedo', 'Alfa Tropical' and 'Pêra IPA 2', suggesting that these two kinds of cytoplasms were common in the Brazilian 'Baia Periforme' derived onion populations (Santos et al., 2007).

We identified male sterile (line 'A') and maintainer (line ' $\mathrm{B}$ ') lines in two years of intensive work, associating random field pairing of fertile plants with selected sterile plants, as previously suggested by Banga and Petiet (1958), with the PCR-based marker system to monitor cytoplasm developed by Sato (1998) and Engelke et al. (2003). These identified 'A' and 'B' lines will be important to develop tropical onion hybrids welladapted to Brazilian low latitudes and with affordable price to growers and also to future comparative studies with other onion CMS commercial systems. Self-pollinated 'S2' and 'S3' families of onion commercial shortday varieties have been produced to be used as ' $\mathrm{C}$ ' lines in order to develop hybrids for further testing in different environments of the São Francisco river valley and also in other parts of Brazil.

\section{Acknowledgements}

This research was supported by $\mathrm{CNPq}$ and BNBEtene.

\section{References}

Araújo, M.T.; Rodrigues, A.G. 1998. Alfa Tropical: Nova cultivar de cebola de verão. p.21. In: Congresso Brasileiro DE Olericultura 38. EMBRAPA-CPATSA/SOB, Petrolina, PE, Brazil.

Banga, O.; Petiet, J. 1958. Breeding male sterile lines Dutch onion varieties as preliminary to the breeding of hybrid varieties. Euphytica 7: 21-30.
Costa, C.P. 1967. Estudo da esterilidade masculina e identificação de linhas complemenares ( $\mathrm{Nmsms}$ ) na variedade brasileira de cebola baia periforme precoce Piracicaba (Allium cepa L). M.Sc. Dissertation. Universidade de São Paulo, São Paulo, SP, Brazil. 32p. (In Portuguese, with Summary in English).

Doyle, J.J.; Doyle, J.L. 1990. Isolation of plant DNA from fresh tissue. Focus 12: 13-15.

Engelke, T.; Terefe, D.; Tatlioglu, T. 2003. A PCR-based marker system monitoring CMS-(S), CMS-(T) and (N)-cytoplasm in the onion (Allium cepa L.). Theoretical and Applied Genetics 107: 162-167.

Havey, M.J. 1995. Identification of cytoplasm using the polymerase chain reaction to aid in the extraction of maintainer lines from open-pollinated populations of onion. Theoretical and Applied Genetics 90: 263-268.

Jones, H.; Clarke, A. 1943. Inheritance of male sterility in the onion and the production of hybrid seed. Proceedings of the American Society for Horticultural Science 43: 189-194.

Leite, D.L. 1999. Molecular characterization of cytoplasmic diversity in leek and south-american onion cultivars and sequencing of onion cDNAs. Dr. Thesis. University of Wisconsin, Madison WI, USA. 120p..

Melo, P.C.T.; Boiteux, L.S. 2001. Análise retrospectiva do melhoramento genético de cebola (Allium cepa L.) no Brasil e potencial aplicação de novas estratégias biotecnológicas. In: Congresso Brasileiro de Melhoramento de Plantas 1. UFG/ SBMP, Goiânia, GO, Brazil. CD-ROM.

Pathak, C.S. 1997. A possible new source of male sterility in onion. Acta Horticulture 433: 313-316.

Santos, M.D.M.; Buzar, A.G.R.; Fonseca, M.E.N.; Oliveira, V.R.; Torres, A.C., Boiteux, L.S. 2007. Caracterização molecular do tipo de citoplasma (N, S e T) em acessos de uma coleção brasileira de germoplasma de cebola. Horticultura Brasileira 25: 103.

Sato, Y. 1998. PCR amplification of CMS-specific mitochondrial nucleotide sequences to identify cytoplasmic genotypes of onion (Allium cepa L.). Theoretical and Applied Genetics 96: 367-370.

Serra, A.D.B.; Currah, L. 2002. Agronomy of onions. p.187-232. In: Rabinowitch, H.D., ed. Allium Crop Science: Recent Advances. CABI, Wallingford, UK.

Szklarczyk, M.; Simlat, M.; Jagosz, B.; Ba, G.Y. 2002. The use of cytoplasmic markers in onion hybrid breeding. Cell and Molecular Biology Letter 7: 625-634.

Received April 02, 2009

Accepted November 18, 2009 